\title{
PERBEDAAN JUMLAH ASUPAN ENERGI, LEMAK, SERAT DAN NATRIUM BERDASARKAN KATEGORI SCREEN-TIME VIEWING PADA ANAK OBESITAS USIA 9-12 TAHUN
}

\author{
Haidar Asshidiqie, Binar Panunggal \\ Program Studi Ilmu Gizi Fakultas Kedokteran Universitas Diponegoro \\ Jl.Dr.Sutomo No.18, Semarang, Telp (024) 8453708, Email : gizifk@undip.ac.id
}

\begin{abstract}
Background : Children obesity occured because of physical inactivity and the lack of well-balance food intake. Watching television, playing laptop, cellphone or game console habits which can be called as daily screen-time viewing was linked to raising obesity prevalence among children. This study was aimed to analize the difference between intake amount of energy, fat, fiber and sodium based on screen-time viewing category among obesed children aged 9-12 years old.

Methods: Subject as many as 80 children participated by filling the informed consent in this cross sectional study. Obesity was defined by body mass index for age Indicator. Energy, fat, fiber and sodium intake obtained via respondent interview (the parents) by the screen-time viewing questionnaire daily for 7 days, then be categorized as Low Screen-time Viewing (LSTV $<21 \mathrm{~h} /$ week) dan High Screen-time Viewing (HSTV $\geq 21 \mathrm{~h} /$ week).

Results: There were significant differences between each energy and fat intake amount based on screen-time viewing group among obesed children aged 9-12 years old. Energy intake amount for LSTV and HSTV group were

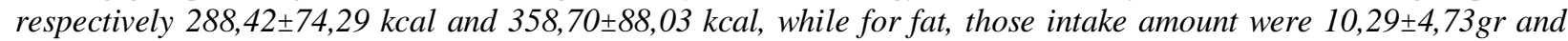
$15,08 \pm 10,79 \mathrm{gr}$. In this study there were no significant difference between amount intake of fiber and sodium based on screen-time viewing category among obesed children aged 9-12 years old.

Conclusion: Each intake amount of energy and fat were lower in LSTV group than the intake amount of energy and fat in HSTV group among obese children aged 9-12 years old.

Keywords: Obesity, intake, energy, fat, fiber, sodium, screen-time viewing
\end{abstract}

\begin{abstract}
ABSTRAK
Latar Belakang: Peningkatan prevalensi obesitas pada anak dapat terjadi karena aktifitas fisik yang rendah serta asupan makan yang tidak seimbang. Kebiasaan menonton televisi, bermain laptop, handphone ataupun game console yang lazim disebut screen-time viewing, dikaitkan dengan kenaikan prevalensi obesitas anak saat ini. Penelitian ini dilakukan untuk membandingkan jumlah asupan makanan (energi, lemak, serat dan natrium) berdasarkan kategori screen-time viewing pada anak obesitas usia 9-12 tahun.

Metode: Sebanyak 80 anak berusia 9-12 tahun berpartisipasi dalam penelitian cross-sectional dengan menyetujui informed consent yang telah disediakan. Penentuan status obesitas ditentukan berdasarkan standar deviasi (SD) indeks massa tubuh terhadap umur. Data asupan energi, lemak, serat dan natrium diperoleh dari hasil wawancara menggunakan kuisioner screen-time viewing tiap hari dengan ketentuan kategori Low Screen-time Viewing (LSTV < 21 jam/minggu) dan High Screen-time Viewing (HSTV $\geq 21$ jam/minggu).

Hasil: Terdapat perbedaan jumlah asupan energi dan lemak berdasarkan kategori screen-time viewing pada anak obesitas usia 9-12 tahun. Jumlah asupan energi kategori screen-time viewing LSTV dan HSTV secara berturut-turut

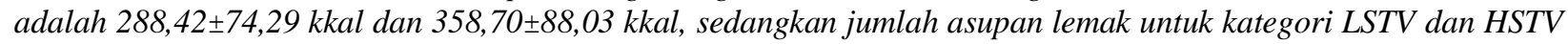

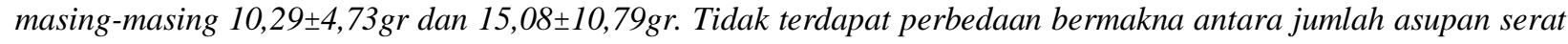
dan natrium berdasarkan kelompok LSTV dan HSTV pada anak obesitas usia 9-12 tahun.

Simpulan: Jumlah asupan energi dan lemak kelompok LSTV lebih rendah dibandingkan jumlah asupan energi dan lemak kelompok pada anak obesitas usia 9-12 tahun.
\end{abstract}

Kata Kunci: Obesitas, asupan, energi, lemak, serat, natrium, screen-time viewing

\section{PENDAHULUAN}

Prevalensi obesitas pada anak di berbagai negara dipengaruhi oleh banyak faktor dan saling berhubungan. Peningkatan jumlah asupan makanan serta aktifitas fisik yang rendah dapat menyebabkan peningkatan berat badan pada anak. Prevalensi obesitas pada anak di dunia pada tahun
2010 sebesar 6,7\% dengan rincian di Asia sendiri terdapat 18 juta anak obesitas $(4,9 \%){ }^{1}$

Prevalensi obesitas anak pada tahun $2010 \mathrm{di}$ Indonesia adalah $9,2 \%{ }^{2}$ Penelitian yang dilakukan Faizah tahun 2004 pada anak usia 6-7 di 15 sekolah dasar negeri dan swasta kota Semarang, didapatkan 126 anak obesitas $(10,3 \%) .{ }^{3}$ Obesitas pada anak dipengaruhi oleh asupan makan yang

${ }^{*}$ Penulis Penanggungjawab 
berlebih dan aktifitas fisik yang kurang. Anak cenderung menggunakan waktu luang sehari-hari untuk menonton televisi, bermain laptop, handphone ataupun game console dibandingkan berolahraga diluar rumah.

Total waktu yang dihabiskan dalam penggunaan media elektronik dalam satu hari disebut dengan screen-time viewing. ${ }^{4}$ Penggunaan media elektronik yang termasuk dalam screen-time viewing diantaranya yaitu menonton televisi, bermain laptop, komputer, handphone serta game console. Rekomendasi screen-time viewing dalam sehari menurut American Academy Of Pediatrics tahun 2006 yaitu $<2$ jam sehari. ${ }^{5}$ Rekomendasi yang ada ternyata tidak sesuai dengan kebiasaan anak sehari-hari seperti penelitian yang dilakukan di Kanada tahun 2006 yang menunjukkan screentime viewing pada anak mencapai rata-rata $>4$ jam sehari. $^{6}$

Screen-time viewing yang masih diatas anjuran menunjukkan besarnya pengaruh media elektronik terhadap aktifitas fisik anak yang berimbas pada asupan makan anak. Hasil yang signifikan tentang pengaruh media dengan status gizi anak yang meningkat sudah terbukti pada penelitian sebelumnya di Yunani tahun 2009. Mekanisme yang melatarbelakangi hasil ini adalah screen-time viewing menggantikan aktivitas fisik sehari-hari sehingga energi yang dikeluarkan menjadi lebih sedikit dan terjadi positive energy balanced. $^{8}$

Kebiasaan menonton televisi dan peningkatan screen-time viewing sering dikaitkan dengan kejadian overweight dan obesitas pada anak-anak. $^{9,10}$ Penelitian pada anak-anak dan remaja menemukan hubungan antara kebiasaan menonton televisi dengan peningkatan asupan jenis makanan tertentu seperti pizza, soda, serta camilan tinggi energi dan lemak. ${ }^{11-13}$ Hasil tersebut didukung penelitian di Amerika tahun 2009 yang menemukan penurunan kualitas makanan yang diasup anak selama screen-time viewing yaitu konsumsi manisan, fast-food, serta jarang mengkonsumsi buah sayur. ${ }^{14}$

Penelitian ini bertujuan untuk mengetahui perbedaan jumlah asupan energi, lemak, serat dan natrium berdasarkan kategori screen-time viewing pada anak obesitas usia 9-12 tahun.

\section{METODE}

Penelitian menggunakan rancangan cross sectional yang melibatkan anak Sekolah Dasar usia 9-12 tahun di kota Semarang. Populasi target penelitian ini adalah anak Sekolah Dasar umur 912 tahun di kota Semarang dengan obesitas.
Populasi terjangkau pada penelitian ini adalah anak Sekolah Dasar umur 9-12 tahun di kota Semarang dengan obesitas di SDN Petompon 02, SD PL Bernadus, dan SD Hj. Isriati Baiturrahman 01. Dari 529 Sekolah Dasar (SD) yang ada di kota Semarang, dipilih 3 SD dengan persentase obesitas tinggi yaitu SD N Petompon 02, SD PL Bernadus, dan SD Hj. Isriati Baiturrahman 01. ${ }^{15}$

Pengambilan subjek penelitian diawali dengan skrining terhadap seluruh siswa di 3 Sekolah Dasar yang berumur 9-12. Pengukuran berat badan menggunakan Timbangan injak digital dengan kapasitas berat maksimal $150 \mathrm{~kg}$ dan tingkat ketelitian $0,1 \mathrm{~kg}$. Pengukuran tinggi badan menggunakan Microtoise dengan panjang maksimal $200 \mathrm{~cm}$ dan tingkat ketelitian $0,1 \mathrm{~cm}$. Pengolahan data skrining menggunakan software WHO Anthroplus untuk penentuan status gizi anak. Penentuan subjek penelitian dengan menggunakan metode simple random sampling dilakukan setelah proses skrining.

Subjek minimal yang dibutuhkan dalam penelitian adalah 76 anak dengan status obesitas. Kriteria inklusi dalam penelitian ini adalah IMT/U lebih dari 2 SD, umur 9-12 tahun, tidak memiliki riwayat penyakit kronis, mampu menjawab pertanyaan melalui wawancara, serta bersedia menjadi subjek penelitian dengan mengisi informed consent. Kriteria eksklusi penelitian yaitu mengundurkan diri menjadi subjek penelitian, dalam keadaan sakit atau perawatan dokter, serta pindah sekolah saat penelitian berlangsung.

Pengumpulan data lanjutan yaitu pengumpulan data asupan makanan (energi, lemak, serat dan natrium) selama screen-viewing diperoleh dengan wawancara menggunakan kuisioner asupan makanan dan Food Recall yang dilakukan sehari sekali selama 1 minggu. Kuisioner ditanyakan kepada orangtua selaku responden bersama dengan anak dan dilakukan tiap satu hari sekali selama 7 hari. Nutrisurvey digunakan untuk pengolahan data asupan makan subjek selama screen viewing.

Screen-time viewing diukur berdasarkan waktu yang dihabiskan untuk beraktivitas didepan televisi, bermain laptop, komputer, handphone serta game console dalam satu hari. Hasil perhari dirata-rata dalam 7 hari sehingga diperoleh screentime viewing dalam ukuran jam/minggu. Kategori screen-time viewing didapat dengan mengkategorikan data screen-time viewing dalam seminggu menjadi Low Screen-time Viewing (LSTV, < $21 \mathrm{jam} / \mathrm{minggu})$ dan High Screen-time Viewing (HSTV, $\geq 21 \mathrm{jam} /$ minggu). ${ }^{14}$ Hasil 
pengkategorian selanjutnya dibandingkan dengan data jumlah asupan energi (kkal), lemak (gr), serat (gr) dan natrium (mg).

Analisis data menggunakan program Statistical Package for Social Science (SPSS) meliputi Analisis bivariat menggunakan uji parametrik independent t-test untuk menguji variabel jumlah asupan energi dan serat, sedangkan uji non-parametrik Mann-whitney untuk uji perbedaan jumlah asupan lemak dan natrium berdasarkan kategori screen-time viewing (dalam satuan jam/minggu).

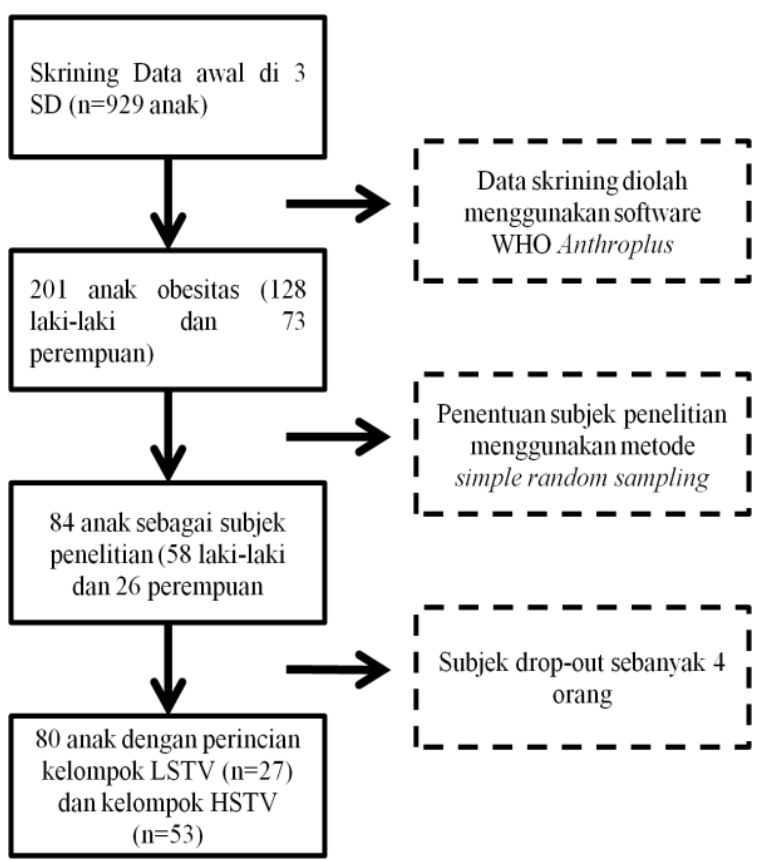

Bagan 1. Alur Kerja Penelitian

\section{HASIL PENELITIAN}

Subjek Penelitian

Hasil skrining dari 929 anak-anak berusia 9-12 tahun di SDN Petompon 02, SD PL Bernadus, dan SD Hj. Isriati Baiturrahman 01 didapatkan sejumlah 201 anak obesitas. Data anak yang termasuk obesitas terdiri dari 128 laki-laki $(63,68 \%)$ dan 73 perempuan $(36,32 \%)$ yang kemudian diacak untuk dijadikan subjek penelitian dengan karakteristik subjek pada Tabel 1 sebagai berikut.

Tabel 1. Karakteristik Subjek Penelitian

\begin{tabular}{lccc}
\hline \multirow{2}{*}{\multicolumn{1}{c}{ Variabel }} & Laki-Laki $(\mathbf{n = 5 7 )}$ & $\begin{array}{c}\text { Perempuan } \\
(\mathbf{n = 2 3})\end{array}$ & Total $(\mathbf{n = 8 0})$ \\
\cline { 2 - 4 } & Mean \pm SD & Mean \pm SD & Mean \pm SD \\
\hline Umur & $10,6 \pm 0,77$ & $10,58 \pm 0,65$ & $10,59 \pm 0,74$ \\
Z-score & $3,06 \pm 0,67$ & $2,57 \pm 0,38$ & $2,92 \pm 0,64$ \\
STV & & & \\
LSTV (Low Screen-time Viewing) & $18,12 \pm 2,52$ & $17,8 \pm 2,11$ & $17,99 \pm 2,33$ \\
HSTV (High Screen-time Viewing) & $25,74 \pm 3,05$ & $24,78 \pm 2,61$ & $25,53 \pm 2,96$ \\
\hline
\end{tabular}

Subjek penelitian sampai akhir penelitian sebanyak 80 orang terdiri dari laki-laki 57 anak $(71,2 \%)$ dan perempuan sebanyak 23 anak $(28,8 \%)$. Sedangkan distribusi umur subjek dengan proporsi paling besar berada pada kisaran umur 10 tahun yaitu 38 orang $(47,5 \%)$. Secara deskriptif, rerata screen-time viewing pada subjek laki-laki lebih besar dibandingkan rerata screen-time viewing pada subjek perempuan.

Kategori Screen-time Viewing 
Screen-time viewing dihitung selama 7 hari kemudian dirata-rata sehingga didapatkan satuan jam/minggu. dan dijumlahkan dalam satu minggu sehingga didapat ukuran dalam jam/minggu. Secara keseluruhan dari data yang terkumpul, rerata screen-time viewing (STV) sebesar
22,98 $\pm 4,52 \mathrm{jam} /$ minggu dengan STV terendah dan tertinggi yaitu 12,81 jam/minggu dan 35,35 jam/minggu. Karakteristik pembagian kelompok screen-time viewing dapat dilihat pada Tabel 2 dan 3.

Tabel 2. Karakterisik Kategori Screen-time Viewing

\begin{tabular}{llccccc}
\hline \multirow{2}{*}{ Kategori Screen-time Viewing } & \multicolumn{2}{c}{ Laki-laki $(\mathbf{n = 5 7})$} & \multicolumn{2}{c}{ Perempuan $(\mathbf{n = 2 3})$} & \multicolumn{2}{c}{ Total $(\mathbf{n = 8 0})$} \\
\cline { 2 - 7 } & $\mathbf{n}$ & $\mathbf{\%}$ & $\mathbf{n}$ & $\mathbf{\%}$ & $\mathbf{n}$ & $\mathbf{\%}$ \\
\hline $\begin{array}{l}\text { Low Screen-time Viewing (LSTV, } \\
\text { jam/minggu) }\end{array}$ & 16 & 28,1 & 11 & 47,8 & 27 & 33,8 \\
$\begin{array}{l}\text { High Screen-time Viewing (HSTV, } \\
\text { jam/minggu) }\end{array}$ & 41 & 71,9 & 12 & 52,2 & 53 & 66,2 \\
\hline
\end{tabular}

Tabel 3. Rerata Screen-time Viewing berdasarkan asal sekolah subjek

\begin{tabular}{lcccccc}
\hline \multirow{2}{*}{ Asal Sekolah } & \multicolumn{2}{c}{$\begin{array}{c}\text { Low Screen-time } \\
\text { Viewing }(\text { LSTV, } \\
\text { jam/minggu) }\end{array}$} & \multicolumn{2}{c}{$\begin{array}{c}\text { High Screen-time } \\
\text { Viewing }(\text { LSTV, } \\
\text { jam/minggu) }\end{array}$} & $\begin{array}{c}\text { Total Screen-time } \\
\text { Viewing (LSTV, } \\
\text { jam/minggu) }\end{array}$ \\
\cline { 2 - 8 } & $\mathbf{n}$ & mean \pm SD & n & mean \pm SD & n & mean \pm SD \\
\hline SDN Petompon 02 & 7 & $18,42 \pm 2,25$ & 18 & $24,68 \pm 2,69$ & 25 & $22,93 \pm 3,82$ \\
SD Hj Isriati 01 & 16 & $18,15 \pm 2,16$ & 24 & $26,19 \pm 3,14$ & 40 & $22,97 \pm 4,85$ \\
SD PL Bernadus & 4 & $16,63 \pm 3,24$ & 11 & $25,45 \pm 2,89$ & 15 & $23,10 \pm 4,95$ \\
\hline
\end{tabular}

Hasil pengkategorian screen-time viewing pada Tabel 2 yaitu kelompok LSTV sebanyak 27 anak $(33,8 \%)$ dan kelompok HSTV sebanyak 53 anak $(66,2 \%)$. Sebagian besar proporsi subjek lakilaki $(71,9 \%)$ dan perempuan $(52,2 \%)$ termasuk dalam kelompok HSTV.

Proporsi jumlah subjek terbesar yang berpartisipasi dalam penelitian berasal dari SD $\mathrm{Hj}$ Isriati 01 sebanyak 40 anak. Secara deskriptif, rerata screen-time viewing dari ketiga sekolah merata dengan rerata terbesar oleh subjek asal SD PL Bernadus dan rerata terendah berasal dari kelompok asal kelompok SDN Petompon 02. Pengkategorian screen-time viewing kedalam kelompok LSTV dan HSTV akan digunakan sebagai dasar analisa uji perbedaan data asupan energi, lemak, serat dan natrium subjek.

Perbedaan Jumlah Asupan Energi, Lemak, Serat dan Natrium berdasarkan Kategori Screen-time Viewing pada Anak Obesitas Usia 9-12 Tahun

Data mengenai jumlah asupan energi, lemak, serat dan natrium didapat dari hasil wawancara dengan subjek dan responden (orangtua subjek) menggunakan kuisioner screentime viewing selama 7 hari. Deskripsi statistik dan hasil uji beda setiap variabel jumlah asupan antara kelompok LSTV dan HSTV (dalam ukuran jam/minggu) disajikan pada Tabel 4.

Tabel 4. Perbedaan Jumlah Asupan Energi, Lemak, Serat dan Natrium perhari berdasarkan Kategori Screen-time Viewing (jam/minggu)

\begin{tabular}{|c|c|c|c|c|c|c|c|}
\hline \multirow[b]{2}{*}{ Variabel } & \multicolumn{3}{|c|}{$\begin{array}{c}\text { Low Screen-time Viewing } \\
(\mathbf{n}=27)\end{array}$} & \multicolumn{3}{|c|}{$\begin{array}{c}\begin{array}{c}\text { High Screen-time Viewing } \\
(n=53)\end{array} \\
\end{array}$} & \multirow[b]{2}{*}{$\mathbf{p}$} \\
\hline & Mean \pm SD & $\begin{array}{l}\text { Nilai } \\
\text { Mini } \\
\text { mum }\end{array}$ & $\begin{array}{l}\text { Nilai } \\
\text { Maks } \\
\text { imum }\end{array}$ & Mean \pm SD & $\begin{array}{l}\text { Nilai } \\
\text { Mini } \\
\text { mum }\end{array}$ & $\begin{array}{c}\text { Nilai } \\
\text { Maksi } \\
\text { mum }\end{array}$ & \\
\hline Asupan Energi (kkal) & $288,42 \pm 74,29$ & $\begin{array}{c}168 \\
5\end{array}$ & 474,4 & $358,70 \pm 88,03$ & $\begin{array}{c}168 \\
1\end{array}$ & 571,8 & $0,001 * *$ \\
\hline Asupan Lemak (gr)* & $10,29 \pm 4,73$ & 4,1 & 22,7 & $15,08 \pm 10,79$ & 4,8 & 86,4 & $0,001 * *$ \\
\hline Asupan Serat (gr) & $1,79 \pm 0,75$ & 0,5 & 3,4 & $1,92 \pm 0,68$ & 0,6 & 4,2 & 0,431 \\
\hline
\end{tabular}


$\begin{array}{llllllll}\text { Asupan Natrium }(\mathrm{mg}) * & 248,06 \pm 135,88 & 52,2 & 512,1 & 265,28 \pm 151,76 & 37,7 & 566,2 & 0,867\end{array}$

Hasil independent t-test dengan derajat kepercayan $95 \%$

*Hasil uji non-parametrik mann-whitney

$* *$ signifikan $(\mathrm{p}<0,05)$

Hasil analisa uji beda setiap variabel asupan makanan (Tabel 4) menunjukkan bahwa terdapat perbedaan jumlah asupan energi (kkal) dengan STV ( $\mathrm{p}<0,05)$. Jumlah asupan energi kelompok Low Screen-time Viewing lebih rendah dibanding kelompok High Screen-time Viewing. Sementara itu, tidak ditemukan perbedaan antara jumlah asupan serat(gr) pada kelompok LSTV dan HSTV ( $p>0,05$ ), namun secara deskriptif jumlah asupan serat lebih rendah pada kelompok LSTV dibandingkan kelompok HSTV.

Terdapat perbedaan bermakna pada jumlah asupan lemak(gr) antara kelompok LSTV dan HSTV ( $\mathrm{p}<0,05)$. Rerata jumlah asupan lemak kelompok LSTV lebih rendah dibanding kelompok HSTV, sedangkan pada variabel jumlah asupan

natrium, tidak ada perbedaan yang bermakna antara jumlah asupan natrium(mg) kelompok LSTV dan HSTV $(p>0,05)$.

Asupan lemak pada subjek dirincikan menjadi asam lemak tak jenuh tunggal / Mono Unsaturated Fatty Acid (MUFA), asam lemak tak jenuh ganda / Poly Unsaturated Fatty Acid (PUFA), asam lemak jenuh / Saturated Fatty Acid (SFA) serta Kolesterol. Jenis lemak paling banyak dikonsumsi baik oleh kelompok LSTV maupun HSTV ialah asam lemak jenuh (SFA) dengan rerata berturut-turut sebesar $4,09 \pm 2,35$ gr $(38,70 \%)$ dan $6,27 \pm 6,21$ gr $(41,57 \%)$. Jenis asupan lemak yang dikonsumsi secara lengkap dapat dilihat pada Diagram 1.

Kelompok LSTV

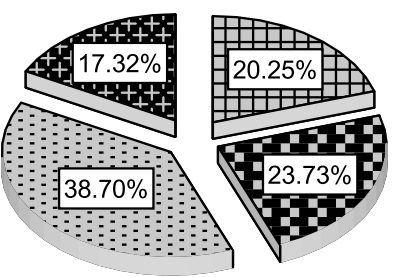

\section{Kelompok HSTV}

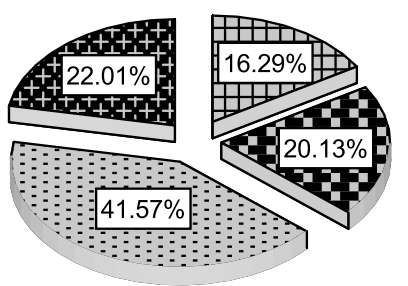

巴Asupan MUFA

Đasupan PUFA

A Asupan SFA

+ Asupan Kolesterol

Diagram 1. Asupan 4 Jenis Lemak selama 7 Hari (gr)

Proporsi asupan natrium subjek penelitian selama screen-viewing yang berasal dari makanan jajanan seperti biskuit, wafer, permen, sosis siap makan, dan minuman isotonik masing-masing pada tiap kelompok screen-time viewing LSTV dan
HSTV sebesar 45,06\% dan 45,53\%. Diagram 2 memperlihatkan persentase asupan natrium dari jajanan pada tiap kelompok dibandingkan asupan natrium yang berasal dari makanan non jajanan (makan utama dan camilan buatan rumah).
Kelompok HSTV
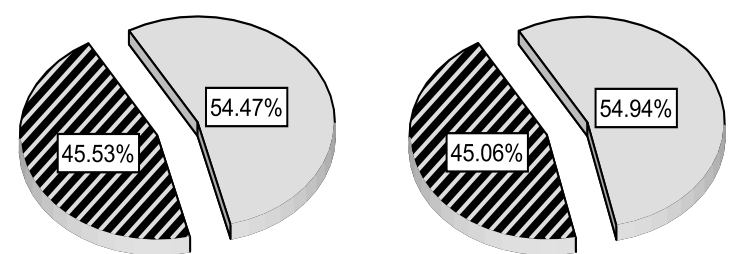

Diagram 2. Perbandingan Asupan Natrium dari Makanan Jajanan dan Non Jajanan 


\section{PEMBAHASAN}

Salah satu penyebab obesitas dapat terjadi akibat kelebihan asupan makanan sehari-hari. Penelitian tahun 2013 di Argentina mengenai asupan makanan dan kejadian obesitas pada anak menyimpulkan bahwa jumlah asupan energi dari makanan perhari rata-rata $115,8 \%$ dari total rekomendasi kecukupan energi sebesar $2000 \mathrm{kkal}^{8}$ Konsumsi makanan yang tidak tepat terutama pada anak-anak akan berpengaruh pada peningkatan berat badan.

Hasil analisa perbedaan jumlah asupan energi antar kategori screen-time viewing terbukti signifikan secara statistik ( $\mathrm{p}<0,05)$. Kelompok HSTV dan LSTV selama penelitian mengkonsumsi cemilan tinggi energi seperti biskuit, crakers dan minuman isotonik dengan hasil rerata jumlah asupan energi kelompok LSTV yang lebih rendah dibandingkan kelompok HSTV. Hasil tersebut sesuai dengan penelitian sebelumnya di Amerika yang juga menemukan adanya pengaruh screenviewing terhadap jumlah energi yang makin banyak dikonsumsi. ${ }^{6}$

Sumbangan energi yang berasal dari makanan dan minuman kemasan sangat beragam. Kandungan energi dari makanan ringan seperti crakers, biskuit dan kripik berkisar antara $80-200$ kkal dalam satu sajian, sedangkan minuman kemasan memiliki energi sebesar 110 - $200 \mathrm{kkal}$ per sajian. Makanan dan minuman berkemasan yang menyumbang energi cukup besar apabila dibandingkan dengan total energi selama screentime viewing menjadi salah satu penyebab adanya perbedaan jumlah asupan energi antar kelompok screen-time viewing.

Energi tidak hanya diperoleh dari karbohidrat, tetapi juga dari asupan lemak yang memberikan sumbangan energi sebesar $9 \mathrm{kkal} / \mathrm{gr}$. Konsumsi lemak yang berlebihan akan berpengaruh pada kesehatan anak. Asupan lemak jenuh sudah diteliti berhubungan dengan kenaikan kadar lemak pada anak obese dan overweight, sehingga pola makan yang benar dan jenis asupan yang sehat perlu diterapkan sejak masa anak. ${ }^{16}$

Kebiasaan makan camilan sangat berpengaruh terhadap asupan lemak seseorang karena saat ini makanan ringan yang diperjualbelikan di pasaran umumnya tidak seimbang gizinya (tinggi energi, lemak dan natrium namun rendah akan serat). Secara deskriptif, rerata jumlah asupan lemak yang lebih rendah ditemukan pada kelompok LSTV daripada kelompok HSTV. Makanan jajanan sebagai sumber lemak makanan sehari-hari banyak dikonsumsi oleh kelompok LSTV maupun HSTV. Makanan jajanan dengan kandungan tinggi lemak lebih banyak dipilih oleh kedua kelompok Screentime viewing untuk dikonsumsi karena lebih praktis serta pilihan rasa beragam dan enak.

Data asupan serat tidak signifikan $(p>0,05)$ yang berarti tidak ada perbedaan antara jumlah asupan berdasarkan kategori screen-time viewing dalam penelitian ini. Hasil berbeda ditemukan pada penelitian di Amerika tahun 2009 dan 2011, yang menemukan hasil kontradiktif yaitu pada penelitian tahun 2009 menyimpulkan bahwa semakin lama screen-viewing dalam sehari maka konsumsi asupan serat menurun. ${ }^{17}$ Sedangkan hasil penelitian tahun 2011 pada subjek wanita dewasa menyimpulkan bahwa serat akan semakin banyak dikonsumsi apabila dikaitkan dengan pengingkatan screen-time viewing. ${ }^{18}$

Jumlah asupan serat antara kelompok LSTV dan HSTV yang berbeda dibandingkan hasil penelitian sebelumnya dapat terjadi akibat adanya perbedaan usia subjek, instrumen pengumpulan data asupan dan screen-time viewing antara penelitian ini dengan penelitian sebelumnya pada tahun 2009 dan 2011 di Amerika. Data asupan serat subjek penelitian pada kedua kelompok menunjukkan bahwa snack cemilan kemasan maupun gorengan lebih banyak dikonsumsi dibandingkan buah dan sayur.

Konsumsi buah dan sayur tidak lepas dari kontribusi karbohidrat kompleks dalam hal ini selulosa dan pati berasal dari makanan seperti serealia, biji-bijian, kentang dan buah-buahan. ${ }^{19}$ Selulosa sebagai salah satu jenis karbohidrat kompleks memiliki fungsi sebagai bulking agent. Bulking agent berperan dalam proses pencernaan terutama di usus besar dalam pembentukan feses serta memperlancar proses defekasi sisa hasil pencernaan. ${ }^{19}$ Pada penelitian ini, makanan jajanan tidak mendeskripsikan produknya secara rinci mengenai kandungan karbohidrat kompleks. Hal ini menyebabkan peneliti tidak bisa menganalisa lebih lanjut mengenai karbohidrat kompleks dalam makanan dan minuman kemasan (jajanan). Konsumsi karbohidrat kompleks (selulosa dan pati) sebagai salah satu sumber asupan serat dapat menjadi penyebab tidak adanya perbedaan rerata asupan serat kelompok LSTV dibandingkan dengan kelompok HSTV.

Asupan Natrium yang tidak berbeda terjadi akibat persebaran data yang tidak merata karena semua anak mengkonsumsi asupan tinggi natrium $(253,05 \pm 139,85 \mathrm{mg})$ dan tidak terpengaruh oleh lamanya screen-viewing dalam jam/minggu. 
Sumbangan natrium dari makanan jajanan pada kelompok LSTV dan HSTV terhadap total asupan natrium berturut-turut sebesar $45.06 \%$ dan $45.53 \%$. Hasil tersebut membuktikan bahwa sebagian besar konsumsi kedua kelompok relatif sama yaitu kebiasaan mengkonsumsi makanan dan minuman kemasan.

Penelitian di Amerika pada tahun 2011 memperlihatkan hasil signifikan antara peningkatan asupan natrium dengan lama screenviewing. ${ }^{17}$ Perbedaan hasil kedua penelitian dilatarbelakangi oleh golongan umur subjek yang tidak sama (anak dengan wanita dewasa), jumlah subjek kelompok LSTV dan HSTV (proporsi hampir 50\% lebih besar HSTV dibanding LSTV), serta penggunaan software pengolah dan instrumen pengambilan data asupan makan subjek yang berbeda (Food Recall dan Food Records termodifikasi selama 7 hari).

Sumber natrium dari makan utama dan camilan buatan rumah antar subjek dalam kelompok HSTV dan LSTV tidak bisa terdefinisi secara jelas karena keterbatasan peneliti untuk mengidentifikasi sumber natrium secara tepat dan hanya mengandalkan ingatan ibu saat pembuatan makanan di rumah. Sumber utama natrium dalam makan yang dibuat dalam skala rumah tangga adalah garam dapur dan penyedap masakan (MSG). Responden hanya memperkirakan seberapa banyak garam atau MSG yang diberikan selama proses memasak (dalam ukuran sendok makan) sehingga hasil asupan rentan terhadap bias.

\section{KETERBATASAN PENELITIAN}

Asupan makanan dan data screen-time viewing diambil hanya melalui tanya jawab dengan orangtua serta tidak melihat secara langsung dapat menimbulkan adanya kerancuan data. Asupan serat dan natrium yang tak bisa terinci lebih lengkap (persentase sumbangan natrium dari garam dapur dan MSG serta serat yang berasal dari konsumsi karbohidrat kompleks) mengakibatkan hasil penelitian tidak mendetail pada natrium dan serat yang diteliti sehingga hanya terbatas pada analisa perbedaan antar kelompok saja.

\section{SIMPULAN}

1. Terdapat perbedaan jumlah asupan energi dan lemak berdasarkan kategori screen-time viewing ( -value $<0,05)$ pada anak obesitas usia 9-12 tahun. Jumlah asupan energi masing-masing kategori screen-time viewing (LSTV dan HSTV) adalah 288,42 $\pm 74,29$ kkal dan $358,70 \pm 88,03 \mathrm{kkal}$, sedangkan jumlah asupan lemak untuk masing-masing kategori tersebut adalah $10,29 \pm 4,73 \mathrm{gr}$ dan $15,08 \pm 10,79$ gr.

2. Tidak ditemukan adanya perbedaan bermakna antara jumlah asupan serat dan natrium kelompok Low Screen-time Viewing (LSTV) dan kelompok High Screen-time Viewing (HSTV) pada anak obesitas usia 9-12 tahun ( $p$-value $>0,05)$.

\section{SARAN}

Perlu peran orang tua dalam memantau screen-time viewing anak sehari-hari agar tidak terlalu sering menghabiskan waktu di depan layar dan lebih mengarahkan penggunaan waktu didepan layar untuk mengerjakan tugas sekolah atau belajar. Untuk penelitian selanjutnya, diperlukan instrumen pengambilan dan pengolahan data asupan makan dengan sensitivitas yang lebih baik agar tetap bisa dipakai untuk mengukur asupan anak selama screen-viewing yang berbedabeda karakteristik tiap individunya tanpa terjadi bias atau dapat menekan bias seminimal mungkin.

\section{UCAPAN TERIMA KASIH}

Puji syukur penulis panjatkan kehadirat Allah SWT, atas rahmat dan segala kemudahan yang telah diberikan. Penulis mengucapkan terima kasih kepada Dosen penguji dan pembimbing atas kritik dan saran yang diberikan. Kepala Sekolah dan Staff Pengajar SD N Petompon 02, SD PL Bernadus, dan SD Hj. Isriati Baiturrahman 01 atas ijin dalam penelitian ini, terima kasih atas waktu dan kerjasamanya selama penelitian. Terima kasih pula kepada orang tua dan keluarga atas doa serta dukungannya. Terima kasih kepada teman-teman gizi UNDIP angkatan 2009 atas dukungannya serta semua pihak yang telah membantu berjalannya penelitian ini.

\section{DAFTAR PUSTAKA}

1. De Onis M., Blössner M., Borghi E. Global Prevalence and Trends of Overweight and Obesity among Preschool Children. American Journal of Clinical Nutrition. 2010;92:1257-64.

2. Kementrian Kesehatan. Riset Kesehatan Dasar (Riskesdas). Kemenkes RI; Jakarta. 2010.

3. Faizah Z. Faktor Risiko Obesitas pada Murid Sekolah Dasar Usia 6-7 Tahun di Semarang (tesis). Semarang : Universitas Diponegoro; 2004.

4. American Academy Of Pediatrics (US). Children, Adolescents and Television. Committee on Public Education. DOI: 10.1542/peds.107.2.423 Pediatrics 2001;107;423. 
5. Mark AE, Boyce WF, Janssen I. Television viewing, computer use and total screen time in Canadian youth. Paediatr Child Health 2006;11(9):595-99.

6. Davies, C.A, Vandelanotte C., Duncan M.J, Van Uffelen Jannique GZ. Associations of Physical Activity and Screen-time On Health related Quality of Life in Adults. Preventive Medicine 55 (2012): 46-9.

7. Manios Y, Kourbala G, Kondaki K, Grammatikakai E, Anastasiadou A, RomaGiannikou E. Obesity and Television Watching in Preschoolers in Greece: The GENESIS Study. Obesity (2009) 17;2047-2053. doi:10.1038/oby.2009.50

8. Kovalskysa I., Rougiera P.I, Amigoa M.P, De Gregoriob M.J, Herscovicia C.R, Karnera M. Food Intake and Anthropometric Evaluation in Schoolaged Children of Buenos Aires. Arch Argent Pediatr 2013;111(1):9-14.

9. Adachi-Mejia A.M, Longacre M.R, Gibson J.J, Beach M.L, Titus-Ernstoff L.T, Dalton M.A. Children with a TV in their bedroom at higher risk for being overweight. International Journal of Obesity 2007; 31: 644-51.

10. Dubois L, Farmer A, Girard M, Peterson K. Social Factors and Television Use During Meals and Snacks is Associated with Higher BMI among PreSchool Children. Public Health Nutrition 2008; 11(12): 1267-79.

11. Matheson DM, Killen JD, Wang Y, Varady A, Robinson TN. Children's food Consumption during Television Viewing. American Journal of Clinical Nutrition. 2004; 79(6): 1088-94.

12. Cleland VJ, Schmidt MD, Dwyer T, Venn AJ. Television Viewing and Abdominal Obesity in Young Adults: Is The Association Mediated by Food and Beverage Consumption during Viewing Time or Reduced Leisure-Time Physical Activity?. American Journal of Clinical Nutrition. 2008;87: $1148-55$.

13. Feldman S., Eisenberg M.E, Neumark-Sztainer D., Story M. Associations between Watching TV during Family Meals and Dietary Intake Among Adolescents. Journal of Nutrition Education and Behavior 2007;39:257-63.

14. Lipsky LM, Iannotti RJ. Associations of Television Viewing With Eating Behaviors in the 2009 Health Behaviour in School-aged Children Study. Arch Pediatr Adolesc Med. 2012;166(5):465-72.

15. Mexitalia M., Herumuryawan M., Sakundarno M., Subagio HW, Soemantri Agustinus. Hipertensi pada Obesitas Masa Anak. Media Medika Indonesia 2010;44:1:1-6.

16. Soegondo S. Perjalanan Obesitas menuju Diabetes dan Penyakit Kardiovaskular. 1st ed. Divisi Metabolik Endokrinologi, Departemen Ilmu
Penyakit dalam, FKUI/RSCM (Jakarta). PT Abbott Indonesia: 2005.

17. Barr-Anderson DJ, Larson NI, Nelson MC, Neumark-Sztnaier D, Story M. Does television viewing predict dietary intake five years later in high school students and young adults? International Journal of Behavioral Nutrition and Physical Activity 2009, 6:7.

18. Milliron BJ, Woolf K, Appelhans B. Dietary Intake During Screen Time Among Premenopausal Women. Nova Science Publishers, Inc. 2011: 6380.

19. Gropper S.S, Smith J.L, Groff J.L. Advanced Nutrition And Human Metabolism (5th Ed). Wasworth, Cengage Learning: 2009, p.63-8. 